\title{
Pengaruh Penambahan Pupuk Padat dan Cair terhadap Pertumbuhan, Jumlah Klorofil dan Kadar Protein Caulerpa racemosa, J.Agardh, 1873 (Ulvophyceae : Caulerpaceae)
}

\author{
Vicky Dimas Pradhika*, Suryono, Sri Sedjati \\ Departemen IImu Kelautan, Fakultas Perikanan dan IImu Kelautan, Universitas Diponegoro \\ JI. Prof. H. Soedarto S.H, Tembalang,Semarang, Jawa Tengah 50275 Indonesia \\ *Corresponding author, e-mail:vickydimas45@gmail.com
}

\begin{abstract}
ABSTRAK : Caulerpa racemosa merupakan salah satu jenis rumput laut hijau yang dapat hidup di daerah pasang surutmaupun daerah yang tenang/bebas dari pasang surut. Setiap tahun permintaan $C$. racemosa di Jepara terus meningkat. Usaha pengembangan budidaya $C$. racemosa perlu dilakukan supaya penyediaan kebutuhan pasar tidak bergantung pada alam. Upaya peningkatan produksi budidaya dapat dilakukan dengan penambahan nutrien di tambak budidaya. Penelitian ini bertujuan untuk mengetahui pengaruh pemberian pupuk padat dan cair terhadap pertumbuhan (berat basah, laju pertumbuhan harian) dan kandungan klorofil serta kadar protein rumput laut $C$. racemosa. Perlakuan yang pada penelitian ini adalahpenambahan pupuk :A (pupuk padat), $B$ (pupuk cair), $C$ (pupuk padat dan cair). Pencapaian berat rata rata rumput laut sebagai berikut: Kontrol= 39,5 \pm 6,36 gram; $A=11,5 \pm 2,12$ gram; $B=18,5 \pm 10,6$ gram; $D=52,6 \pm 14,19$ gram. Laju pertumbuhan spesifik $C$. racemosa adalah: $A=1,2 \pm 0,37 \% ; B=-1,64 \pm 0,51 \% ; C=-$ $0,53 \pm 0,89 \% ; C=1,7 \pm 0,63 \%$. Kandungan klorofil a $C$. racemosa pada minggu 6 yaitu: Kontrol= $0,022 \mathrm{mg} / \mathrm{gram} ; A=0,015 \mathrm{mg} / \mathrm{gram} ; \mathrm{B}=0,017 \mathrm{mg} / \mathrm{gram} ; \mathrm{C}=0,080 \mathrm{mg} / \mathrm{gram}$. Kandungan klorofil b $C$. racemosa pada minggu ke 6 yaitu: $A=0,016 \mathrm{mg} / \mathrm{gram} ; B=0,018 \mathrm{mg} / \mathrm{gram} ; C=0,013 \mathrm{mg} / \mathrm{gram}$; $\mathrm{D}=0,026$. Kandungan protein sebelum pemberian perlakuan adalah $0,60 \%$ sedangkan setelah diberiperlakuan yaitu: Kontrol=0,70\% $\pm 0,06 ; A=0,75 \% \pm 0,11 ; B=0,60 \% \pm 0,10 ; C=0,73 \% \pm$ 0,08 . Hasil penelitian ini menunjukkan bahwa pemberian pupuk padat dan cair berpengaruh nyata pada berat basah dan laju pertumbuhan spesifik $C$. racemosa $(p<0,01)$ sedangkan pemberian pupuk tidak bepengaruh nyata pada kandungan klorofil dan kadar protein $(p>0,05)$.
\end{abstract}

Kata Kunci: Petumbuhan, Pupuk padat, Pupuk cair, Klorofil, Protein.

\section{Effect of Addition of Solid and Liquid Fertilizers on Growth, Chlorophyll and Protein Contents of Caulerpa racemosa, J.Agardh, 1873 (Ulvophyceae: Caulerpaceae)}

ABSTRACT : Caulerpa racemosa is a type of green algae that can live's in tidal areas and calm / free from tides. Every year the demand for $C$. racemosa in Jepara is continues to increase. Cultivation of $C$. racemosa need to be done so the market suply is not dependent only on nature. Efforts to increase culture production can be done by adding nutrients to aquaculture ponds. This study aims to determine the effect of solid and liquid fertilizer on growth (wet weight, daily growth rate), chlorophyll content and protein content of $C$. racemosa seaweed. Treathments of this study is fertilize additon: $A$ (solid fertilizer), $B$ (liquid fertilizer), $C$ (solid and liquid fertilizer). The average weight of seaweed for 42 days is as follows: Control $=39.5 \pm 6.36$ grams; $A=11.5 \pm 2.12$ grams; $B$ $=18.5 \pm 10.6$ grams; $C=52.6 \pm 14.19$ grams. Specific growth rates of $C$. racemosa produced for 42 days is: Control $=1.2 \pm 0.37 \% ; A=-1.64 \pm 0.51 \% ; B=-0.53 \pm 0.89 \% ; C=1.7 \pm 0.63 \%$. $C$. racemosa's Chlorophyll a content at week 6 is: Control $=0.022 \mathrm{mg} / \mathrm{gram} ; A=0.015 \mathrm{mg} / \mathrm{gram} ; B=$ $0.017 \mathrm{mg} / \mathrm{gram} ; C=0.080 \mathrm{mg} / \mathrm{gram}$. $C$. racemosa's Chlorophyll $b$ content at week 6 is: Control $=$ $0.016 \mathrm{mg} / \mathrm{gram} ; A=0.018 \mathrm{mg} / \mathrm{gram} ; B=0.013 \mathrm{mg} / \mathrm{gram} ; C=0.026 \mathrm{mg} / \mathrm{gram}$. Protein content before administration of treatment is $0.60 \%$ while after treatment, is: Control $=0.70 \% \pm 0.06 ; A=$ $0.75 \% \pm 0.11 ; B=0.60 \% \pm 0.10 ; C=0.73 \% \pm 0.08$. The results of this study showed, the addition of solid and liquid fertilizers had a significant effect on wet weight and specific growth rate of $C$. racemosa $(p<0.01)$ while fertilizer application did not significantly affect chlorophyll content and protein content $(p>0.05)$.

Keywords: Growth, solid fertilizer, liquid fertilizer, chlorophyll, protein 


\section{PENDAHULUAN}

Rumput laut Caulerpa racemosa merupakan salah satu jenis rumput laut hijau (Chlorophyta) yang dapat hidup di daerah pasang surut (laut) maupun daerah yang tenang/bebas dari pasang surut (tambak). Algae hijau jenis ini dapat beradaptasi secara cepat dengan lingkungannya, selain itu memiliki tingkat ketahanan hidup yang tinggi.

Caulerpa racemosa merupakan rumput laut yang menjadi komoditas yang cukup digemari dan sering dikonsumsi oleh masyarakat pesisir. Akan tetapi, ketersediaannya masih sangat bergantung pada alam di laut karena belum ada teknik budidaya yang mampu menghasilkan $C$. racemosa dalam jumlah yang maksimal. $C$. racemosa memerlukan beberapa faktor penting untuk dapat hidup dengan baik meliputi kualitas bibit, faktor lingkungan, hama, metode yang dipakai, dan yang paling penting adalah ketersediaan nutrien.

Menurut Ma'ruf (2013), setiap tahun permintaan C. racemosa di Jepara terus meningkat. Permintaan pasar yang sangat tinggi memaksa masyarakat untuk terus mengambil $C$. racemosa dari alam karena belum banyak kegiatan budidaya $C$. racemosa yang dilakukan masyarakat Jepara. Kegiatan Budidaya ini penting dilakukan untuk menjaga jumlah $C$. racemosa di alam agar tetap tersedia. Salah satu upaya yang dapat dilakukan untuk menjaga ketersediaan $C$. racemosadi alam adalah dengan melakukan kegiatan budidaya, sehingga pengambilan $C$. racemosa tidak terus bergantung pada alam di musim tertentu.

Cara untuk meningkatkan produksi tambak dalam kegiatan budidaya adalah dengan pemupukan atau penambahannutrien yang berasal dari pupuk organik dan anorganik. Kedua pupuk yang mengandung nutrien ini sangat mudah ditemukan dipasaran karena memiliki sangat banyak manfaat untuk tanaman (Kushartono et al., 2009). Pemberian nutrien tambahan berupa pupuk dapat meningkatkan hasil produksi dari rumput laut $C$. racemosa, namun perlu diperhatikan bahwa penggunaannya harus memakai takaran yang tepat sehingga penyerapan dapat berlangsung secara maksimal. Penggunaan pupuk atau nutrien tambahan ini dapat efektif untuk meningkatkan produksi $C$. racemosa sehingga tidak bergantung lagi pada alam di musim.

Tujuan dari penelitian ini adalah untuk mengetahui pengaruh pemberian pupuk padat dan cair terhadap pertumbuhan (berat basah, laju pertumbuhan harian) dan kandungan klorofil serta kadar protein rumput laut Caulerpa racemosa.

\section{MATERI DAN METODE}

Materi yang digunakan dalam penelitian ini adalah rumput laut $C$. racemosa yang diambil dari BBPBAP Jepara, pupuk padat (NPK) dan pupuk cair (Supermes). Pupuk padat mengandung $\mathrm{N} 16 \% ; \mathrm{P} 16 \%$ dan $\mathrm{K} 16 \%$, sedangkan pupuk cair mengandung C- Organik $12 \% ; \mathrm{N} \mathrm{3 \%} ; \mathrm{P}_{2} \mathrm{O}_{5} 3,8 \%$; $\mathrm{K}_{2} \mathrm{O} 3,6 \%$; Cu 0,09\%; Mg 0,09\%; Fe 0,07\%; B 0,06\%: Mn 0,08\%.

Metode yang digunakan dalam penelitian ini adalah metode eksperimental laboratoris yang berguna untuk mengetahui hubungan sebab dan akibat menggunakan satu atau lebih kondisi perlakuan yang dibandingkan dengan variabel kontrol (Budiyani et al., 2012). Penelitian ini dilakukan untuk melihat pertumbuhan, kadar protein dan kadar klorofil rumput laut setelah media diberikan pupuk padat dan cair. Prosedur dari penelitian ini meliputi persiapan sampel dan media, penimbangan berat basah awal rumput laut, pengecekan parameter perairan, persiapan pupuk untuk pemberianperlakuan yang berbeda, uji protein pada awal penanaman, penimbangan berat basah, uji kandungan klorofil dan uji protein pada akhir penanaman.

Langkah pertama untuk melakukan penelitian ini berupa persiapan wadah. Wadah berupa ember untuk proses aklimatisasi rumput laut. Selain itu disiapkan 12 buah akuarium kaca volume 15,625 Liter untuk tempat penanaman rumput laut. Media yang disiapkan berupa air laut steril dengan salinitas 33 ppt. Setelah wadah telah siapselanjutnya rumput laut disiapkan. Rumput laut yang telah diaklimatisasi ditimbang sebanyak $25 \mathrm{gram}$, sebanyak 12 sampel. Selanjutnya rumput laut dimasukkan ke akuarium yang telah diisi dengan media air laut steril. Selanjutnya media akan ditambahkan pupuk yang telah diencerkan dalam 1 liter airpada masing masing akuarium sesuai perlakuan. Sampel kontrol tidak memerlukan tambahan pupuk, Perlakuan A ditambahkan $2 \mathrm{ml}$ pupuk padat, perlakuan B ditambahkan $2 \mathrm{ml}$ pupuk cair, perlakuan $\mathrm{C}$ ditambahkan $1 \mathrm{ml}$ pupuk padat dan $1 \mathrm{ml}$ pupuk cair. 
Selama masa penelitian selama 42 hari dilakukan pengecekan parameter kualitas perairan. Pengukuran parameter kualitas perairan di media $C$. racemosa meliputi suhu, $\mathrm{pH}$ dan salinitas. Pengukuran ini akan dilakukan setiap 2 hari sekali dan salinitasakan disesuaikan bila sudah melebihi batas salinitas untuk hidup rumput laut, yaitu 30-35 ppt. Suhu akan diukur menggunakan termometer, $\mathrm{pH}$ dengan $\mathrm{pH}$ meter dan salinitas diukur menggunakan refraktometer.

\section{Pengamatan dan Penimbangan Berat Basah}

Selain parameter perairan rumput laut juga diamati perubahan fisiknya. Perubahan fisik diamati setiap hari selama 42 hari, pengamatan ini berupa berubahan warna dan tekstur rumput laut. Kemudian rumput laut ditimbang berat basahnya setiap 7 hari sekali untuk mengetahui nilai laju pertumbuhan. Menurut Alamsjah et al., (2009), laju pertumbuhan ini dihitung sebagai parameter utama pengaruh perlakuan berbeda terhadap kondisi rumput laut $C$. racemosa yang ditanam. Laju pertumbuhan sering disebut dengan Spesific Growth Rate (SGR) dan dapat menghitung menggunakan rumus: SGR $=((\ln \mathrm{Wt}-\mathrm{In}$ Wo $) / \mathrm{t}) \times 100 \%$. Keterangan: SGR $=$ Spesific Growth Rate; $\mathrm{Wt}=$ massa rata-rata pada waktu ke-t; $\mathrm{Wo}=$ massa rata-rata awal (gram); $\mathrm{T}$ = waktu (hari)

Uji Protein dari rumput laut akan dilakukan pada $T_{0}$ dan $T_{42}$. Pengujian ini bertujuan untuk mengetahui kadar protein $C$. racemosa sebelum dan setelah dilakukan perlakuan berbeda dengan penambahan pupuk padat, cair maupun kombinasi keduanya. Uji klorofil dilakukan dengan menimbang $C$. racemosa sebanyak 2 gram menggunakan timbangan digital. Kemudian dihaluskan menggunakan mortar. Proses ekstraksi menggunakan pelarut aseton dan metanol dengan perbandingan $3: 7(\mathrm{v} / \mathrm{v})$, ekstrak disaring menggunakan kertas saring, residu diekstrak ulang dengan pelarut yang sama sampai semua pigmen terangkat (Kusmita, 2007). Setelah ekstrak didapat, sampel ekstrak tersebut diuji menggunakan spektrofotometer untuk mengetahui nilai absorbansinya, menurut Akmal (2012) nilai absorbansi ini digunakan untuk menentukan kandungan klorofil a dan b menggunakan rumus berikut:

$$
\begin{aligned}
& \text { Klorofil a }(\mathrm{mg} / \mathrm{g})=\frac{12,7 \times D 663-2,69 \times D 645}{1000 \times W} \times V \\
& \text { Klorofil } b(\mathrm{mg} / \mathrm{g})=\frac{22,9 \times D 663-4,68 \times D 645}{1000 \times W} \times V
\end{aligned}
$$

Keterangan: $\mathrm{D}=$ Nilai absorbansi pada panjang gelombang tertentu; $\mathrm{V}=$ Volume pelarut; $\mathrm{W}=$ Berat thallus rumput laut (gram)

Data yang diperoleh dalam penelitian ini berupa berat basah, SGR, kadar protein dan kandungan klorofil dari $C$. racemosa yang diberi perlakuan berbeda. Data SGR dan protein dianalisis dengan menggunakan analisis varian (ANOVA) untuk mengetahui pengaruh perlakuan. Sebelum dilakukan uji ANOVA, terlebih dahulu dilakukan uji normalitas dan homogenitas. Uji tersebut merupakan syarat yang harus dipenuhi untuk melakukan uji ANOVA dengan mengetahui sifat data tersebut normal dan homogen (Alamsjah et al., 2009). Data berupa time series seperti kandungan klorofil dan berat basah dianalisis menggunakan ANOVA repeated measure untuk mengetahui hubungan antara subjek yang berkaitan.

\section{HASIL DAN PEMBAHASAN}

Berdasarkan penelitian yang telah dilakukan diperoleh data berupa hasil pengukuran pertumbuhan C. racemosa (berat basah), kadar klorofil dan kadar protein pada awal dan akhir penelitian. Hasil penelitian ditampilkan secara deskriptif serta dalam bentuk grafik. Grafik Berat Basah rumput laut dapat dilihat pada Gambar 1.

Hasil dari penelitian ini menunjukkan bahwa $C$. racemosa yang diberikan perlakuan berbeda dengan penambahan pupuk padat dan cair mengalami pertambahan berat basah dengan ukuran yang berbeda beda pada setiap masing masing perlakuan. Rumput laut menunjukkan indikasi pertumbuhan setiap harinya, hal ini dapat dilihat pada grafik berat basah yang ada pada Gambar 1. Hasil dari uji Repeated Measure Anova juga menunjukkan adanya perbedaan nyata pada setiap 
perlakuan yang telah diberikan, nilai sig $=0,001$ atau $p<0,01$ sehingga dapat dipastikan bahwa pemberian perlakuan terhadap berat basah berbeda nyata.

Grafik berat basah (Gambar 1) menunjukkan penggunaan pupuk campuran padat dan cair (Perlakuan C) menghasilkan berat basah yang lebih besar disertai dengan pertumbuhan yang stabil. Total berat basah yang didapatkan perlakuan $C$ sebesar 52,6 gram, diikuti hasil terbaik kedua adalah kontrol (tanpa pupuk) dengan berat berat basah 39,5 gram. Perlakuan A (pupuk padat) dan $C$ (pupuk cair) menunjukkan hasil akhir yang kurang baik yaitu 11,5 gram dan 18,5 gram. Total berat basah akhir pada B dan $C$ lebih kecil dari berat basah awal saat penanaman, hal ini mengindikasikan adanya kematian pada sampel C. racemosa di perlakuan A dan $\mathrm{C}$.

Perlakuan $\mathrm{C}$ mendapatkan berat basah tertinggi karena rumput laut mendapat nutrien yang cukup dan seimbang untuk pertumbuhannya, unsur makro yang didapat dari pupuk padat berupa $\mathrm{N}$ dan $\mathrm{P}$ seimbang dengan unsur mikro yang didapat dari pupuk cair yang berupa $\mathrm{Fe}, \mathrm{Cu}, \mathrm{Mn}$.

Hasil dari penelitian pada perlakuan $\mathrm{C}$ sesuai dengan penelitian yang telah dilakukan Silviana (2009) yang menjelaskan bahwa pertumbuhan rumput laut yang baik dapat disebabkan karena nutrien yang tersedia seimbang antara makro dan mikro nutrien.

Perlakuan A mendapatkan hasil berat basah paling rendah pada saat akhir pengukuran, berat basah yang didapatkan saat $T_{42}$ hanya sebesar 11,5 gram. Perlakuan $A$ yang menggunakan pupuk padat diduga tidak memenuhi nutrien yang seimbang untuk $C$. racemosa. Perlakuan $A$ mulai mengalami kematian pada $T_{21}$, namun pada $T_{7}$ sampai $T_{14}$ rumput laut sempat mengalami pertumbuhan yang cukup baik, mencapai berat basah total sebesar 33,3 gram. Kematian yang dialami sampel diduga karena nutrien pada perairan mengalami penumpukan. Unsur $\mathrm{N}$ yang berlebihan akan menghambat pertumbuhan tanaman, hal ini dapat menyebabkan warna tanaman menjadi gelap atau lebih tua sukelen pertumbuhan vegetatif yang hebat dan tanaman menjadi mudah rusak (Marschner, 1986).

Perlakuan B mendapatkan berat basah akhir sebesar 18,5 gram, berat basah ini lebih sedikit dari waktu penanaman awal dikarenakan adanya kematian pada sampel di akhir masa tanam. Kematian pada sampel perlakuan $B$ dimulai pada $T_{21}$ sampai $T_{42}$. Kematian ini terlihat jelas pada grafik yang ada pada Gambar 2, ditunjukkan dengan pola menurun. Penggunaan pupuk cair sebenarnya sangat baik untuk pertumbuhan namun apabila digunakan dengan takaran tidak tepat akan memicu pertumbuhan mikroba dan organisme lain karena pupuk cair ini mengandung material organik yang cukup banyak. Menurut Hartatik (2015), salah satu kelemahan pupuk cair yang berasal dari tumbuhan adalah mengandung banyak bakteri dan mikroorganisme yang dapat menyebabkan alelopati pada tanaman apabila penggunaan pupuk dilakukan secara terus menerus.

Hasil perhitungan jumlah klorofil a dan b yang telah diamati selama 2 minggu sekali dalam 6 minggu menggunakan spektrofotometer menunjukkan angka yang berbeda pada setiap perlakuannya. Hasil dari perhitungan kandungan klorofil dapat dilihat pada Gambar 2 dan 3.

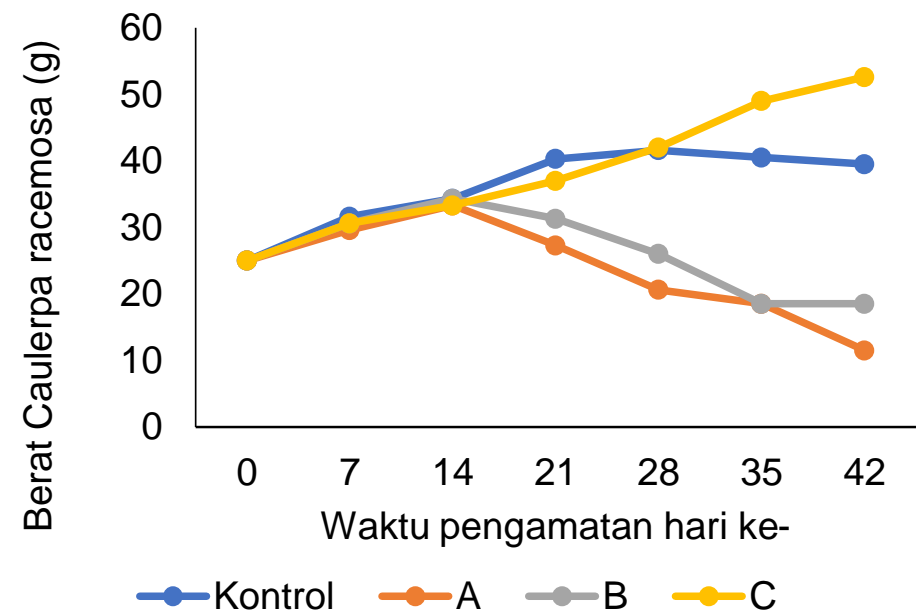

Gambar 1. Grafik Berat Basah C. racemosa selama 42 Hari Pengamatan 


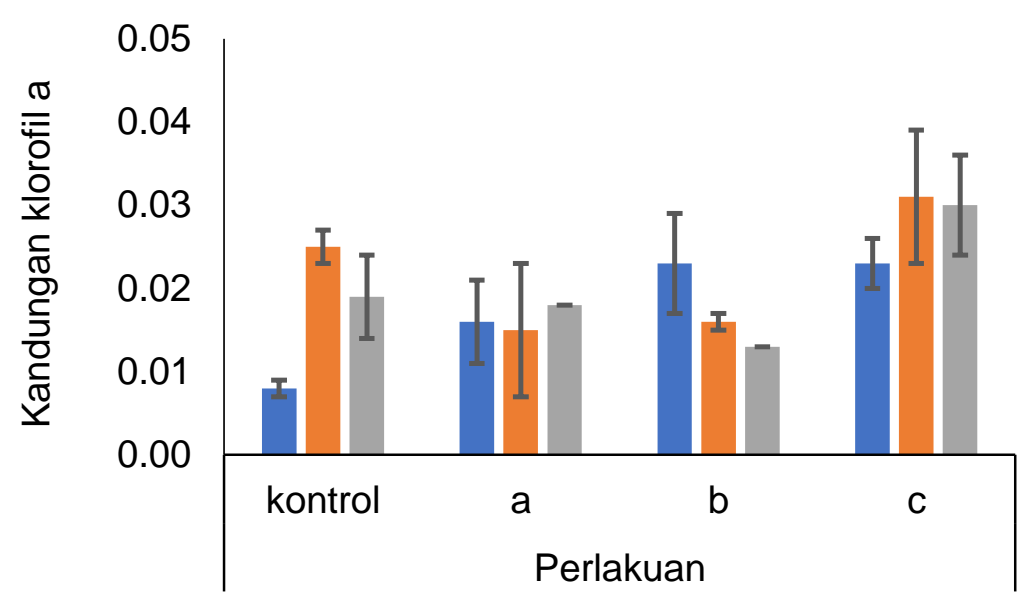

minggu $2 \quad$ minggu $4 \quad$ minggu 6

Gambar 2. Grafik Kandungan Klorofil a

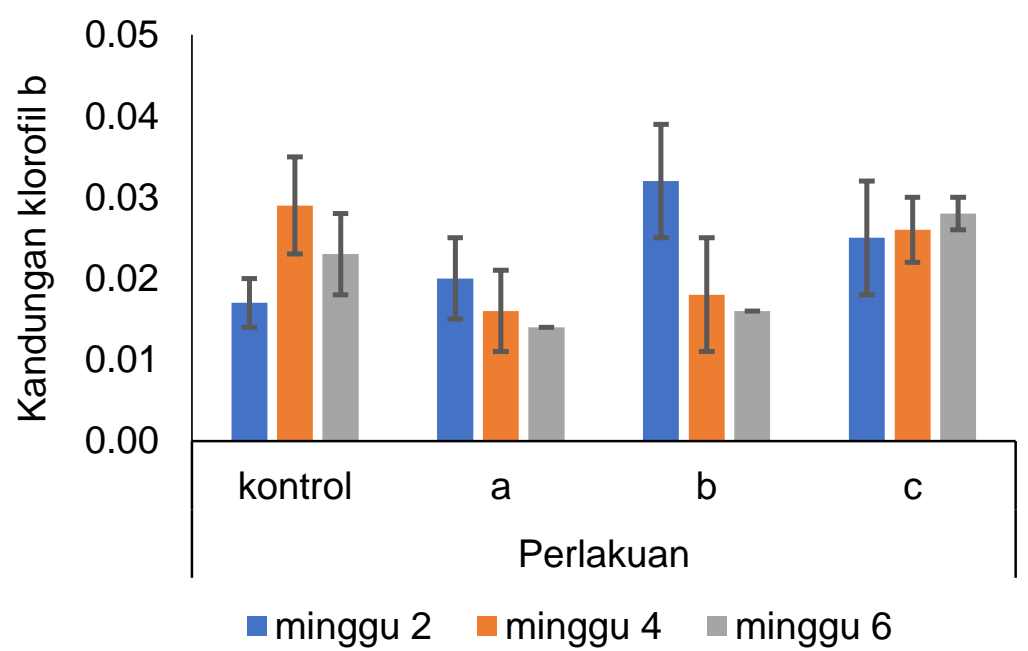

Gambar 3. Grafik Kandungan Klorofil b

Grafik di atas menunjukkan adanya peningkatan nilai standar deviasi pada perlakuan B. Hal ini disebabkan karena rumput laut pada sampel B mengalami kerusakan pigmen akibat kematian rumput laut sehingga kandungan klorofil yang didapatkan menurun secara drastis dan menyebabkan nilai standar deviasi meningkat. Hasil perhitungan kandungan klorofil a dan b pada setiap perlakuan menunjukkan bahwa klorofil a jumlahnya lebih banyak dibandingkan klorofil $b$. Kandungan klorofil a yang lebih banyak dibandingkan klorofil b mengindikasikan pencahayaan dan unsur hara yang diterima oleh tanaman sudah cukup terpenuhi untuk proses fotosintesis.

Data klorofil pada minggu ke 2 menunjukkan bahwa jumlah klorofil a paling banyak dicapai pada sampel perlakuan B dengan perlakuan penambahan pupuk cair. Kandungan klorofil tertinggi selanjutnya pada minggu ke 2 adalah sampel C (pupuk padat dan cair), A (padat), kemudian Kontrol (tanpa pupuk). Pada minggu ke 4 terjadi penurunan kandungan klorofil pada sampel A dan $\mathrm{B}$, hal ini disebabkan banyaknya kematian pada sampel dan kerusakan pigmen sehingga kandungan klorofil juga mengalami penurunan. Kandungan klorofil pada perlakuan B lebih banyak dari perlakuan lainnya, hal ini karena pembentukan klorofil memerlukan unsur tambahan seperti $\mathrm{Mn}$, Cu dan Zn. Unsur tersebur terdapat pada pupuk cair yang diberikan kepada sampel B, sehingga pembentukan klorofil dapat lebih maksimal pada perlakuan ini. Sesuai dengan pernyataan Dwidjoseputro (1980) bahwa klorofil memerlukan unsur makro mikro yang seimbang supaya dapat terbentuk dengan maksimal, unsur tersebut meliputi $\mathrm{N}, \mathrm{P}, \mathrm{C}, \mathrm{Mn}, \mathrm{Zn}$, dan $\mathrm{Cu}$. 
Hasil dari penelitian ini menyatakan bahwa unsur hara yang diberikan melalui pupuk padat, cair maupun campuran dapat mempengaruhi kandungan klorofil yang ada pada rumput laut, namun hal itu tidak berpengaruh nyata atau perubahannya tidak signifikan. Hal tersebut sesuai dengan hasil uji RMA yang menunjukkan $p>0.05$ sehingga dapat dipastikan penambahan pupuk tidak berpengaruh nyata terhadap jumlah klorofil.

Laju pertumbuhan spesifik $C$. racemosa selama 42 hari disajikan pada Gambar 4 menunjukkan nilai SGR pada Kontrol $=1,2 \%$ per hari, $B=-1,64 \%$ per hari, $C=-0,53 \%$ per hari sedangkan $D=1,7 \%$ per hari. Hasil ini berbeda bergantung pada masing masing perlakuan yang telah diberikan, hasil yang paling baik ditunjuakn pada perlakuan $\mathrm{C}$ dengan SGR mencapai 1,7\% per hari.

Perlakuan C mencapai nilai SGR tertinggi diantara perlakuan lainnya karena menggunakan pupuk padat dan cair yang memiliki nutrien lengkap dan seimbang sehingga mencukupi kebutuhan pertumbuhan rumput laut. Rumput laut memerlukan adanya nutrien, baik makro maupun mikro. Hasil SGR perlakuan C sesuai dengan pendapat Alamsjah (2009), rumput laut akan tumbuh dengan cepat dan baik apabila nutrien esensial (makro dan mikro) terpenuhi. Jika salah satu nutrien tidak tersedia, maka dapat menyebabkan pertumbuhan, perkembangan serta produksi rumput laut terhambat.

Perlakuan A mendapatkan nilai SGR paling rendah karena banyak terjadi kematian pada rumput laut. Nilai SGR di bawah $0 \%$ menunjukkan adanya kematian pada objek yang diuji. Kematian diduga karena nutrien menumpuk dan tidak dapat diserap secara maksimal. Kelebihan unsur $\mathrm{N}$ menyebabkan tanaman rusak dan layu (Marschner, 1986).

Perlakuan B mendapatkan nilai SGR sebesar $-0,53 \%$. Pertumbuhan pada perlakuan B mengalami peningkatan pada minggu pertama masa penanaman secara cepat, hal ini dikarenakan unsur organik (karbon) dan unsur mikro yang terdapat pada pupuk cair dapat memicu pertumbuhan rumput laut dengan cepat. Menurut Erlania (2013) kandungan karbon dalam perairan akan diserap rumput laut untuk proses pembentukan energi dan karbohidrat, sehingga perairan dengan unsr karbon cukup akan mempercepat pertumbuhan rumput laut. Namun pada akhir masa tanam, sampel B banyak mengalami kematian yang menyebabkan nilai SGR menurun. Kematian ini disebabkan karena mikroorganisme dan algae lain yang tumbuh di media tanam perlakuan B akibat zat organik berlebih di media tanam.

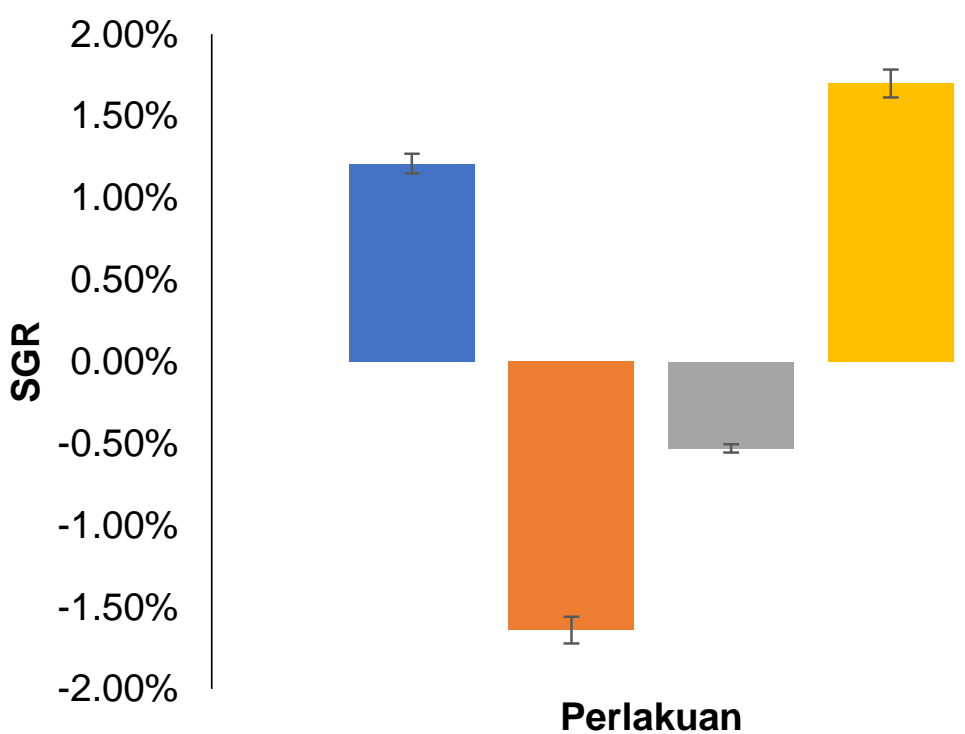

$\square \mathrm{A}($ Kontrol) $\quad \mathrm{B}($ pupuk padat $) \quad \square \mathrm{C}$ (pupuk cair) $\quad \mathrm{D}$ (pupuk campuran)

Gambar 4. Grafik SGR Rumput laut C. racemosa 


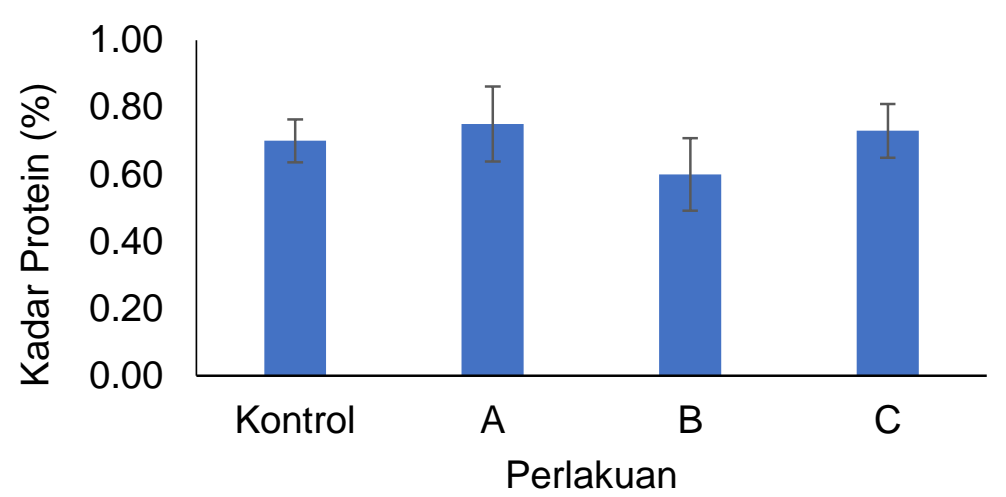

Gambar 5. Grafik Kandungan Protein Rumput Laut Caulerpa racemosa Setelah Pemberian Perlakuan

Sampel kontrol memiliki nilai SGR 1,21\%, nilai tersebut cukup tinggi dibandingkan perlakuan A dan $C$, hal ini diduga karena tidak ada faktor pengganggu lain di media kontrol seperti pada perlakuan A dan C. Sampel kontrol mengalami pertumbuhan yang cukup stabil namun tidak maksimal, karena tidak ada penambahan nutrien, sehingga akan habis secara perlahan. Uji kadar protein dilakukan sebelum dan setelah perlakuan diberikan. Kadar protein C. racemosa dapat dilihat pada Gambar 5.

Hasil uji kadar protein yang telah dilakukan saat $T_{0}$ dan $T_{42}$ menunjukkan adanya perubahan. Kadar protein pada semua sampel mengalami peningkatan. Peningkatan kadar protein pada rumput laut diduga karena rumput laut mendapat tambahan unsur $\mathrm{N}$ yang berasal dari pupuk padat maupun cair. $\mathrm{N}$ akan diserap rumput laut untuk menyusun protein yang nantinya diperlukan untuk membentuk sel sel rumput laut tersebut.

Kadar protein tertinggi didapat pada perlakuan $\mathrm{A}($ Gambar 5). Hal tersebut diduga karena perlakuan A menggunakan pupuk padat (NPK) sebagai perlakuan, pupuk ini mengandung unsur $\mathrm{N}$ paling tinggi diantara pupuk lainnya sebagai perlakuan. Sesuai dengan pendapat Campbell et al. (1999) bahwa unsur $\mathrm{N}$ di perairan akan diserap dan diubah menjadi protein oleh tanaman.

Protein pada tanaman atau algae memerlukan unsur $\mathrm{N}$ untuk dapat disintesis, menurut penelitian yang telah dilakukan. Unsur $\mathrm{N}$ pada pupuk akan mempengaruhi jumlah protein yang dihasilkan oleh algae, hal tersebut dikarenakan unsur $\mathrm{N}$ akan diserap tanaman sebagai penyusun asam amino. Unsur $\mathrm{N}$ diserap tanaman dalam bentuk Nitrat. Nitrat direduksi menjadi asam amino $\left(\mathrm{NH}_{2}\right)$ oleh enzim nitrat reduktase yang membutuhkan energi kegiatan metabolisme seluler. Asimilasi amonium berlangsung cepat sekali, membentuk senyawa $\mathrm{N}$ organik, asam glutamat. Asam-asam amino kemudian dapat disusun menjadi protein-protein tanaman dalam ribosom (Ladyba, 2017).

Hasil penelitian ini menunjukkan peningkatan kadar protein pada setiap sampel, walaupun analisis ANOVA menunjukkan hasil yang tidak berbeda nyata yaitu nilai sig sebebsar 0,167 atau $p$ $>0,05$ tetapi setiap perlakuan cenderung mengalami kenaikan kadar protein. Hal ini sesuai dengan penelitian Chrismada (2006) yaitu pemberian unsur $N$ melalui pupuk nitrogen akan meningkatkan kadar protein pada algae karena akan mempermudah sintesis protein yang dilakukan algae tersebut. Penelitian Yarti (2014) juga menyebutkan bahwa pada media yang diberikan pupuk nitrogen dengan konsentrasi $100 \mathrm{gr} / \mathrm{L}$ menghasilkan kadar protein 0,84\%, sedangkan media dengan 50gr/L nitrogen hanya menghasilkan $0,64 \%$ protein. Data tersebut menunjukkan bahwa unsur nitrogen dapat mempengaruhi kadar protein dalam alga walaupun hanya mengalami sedikit peningkatan.

\section{KESIMPULAN}

Perlakuan penambahan pupuk padat dan cair maupun pupuk campuran berpengaruh nyata terhadap berat basah dan nilai laju pertumbuhan (SGR) Caulerpa racemosa. Pupuk campuran (perlakuan C) menghasilkan berat basah paling tinggi yaitu 52,6 gram dan SGR sebesar 1,7\%. 
Pupuk padat dan cair tidak berpengaruh nyata terhadap pertambahan kandungan klorofil dan kadar protein pada rumput laut Caulerpa racemosa.

\section{DAFTAR PUSTAKA}

Alamsjah, M.A., Tjahjaningsih, W. \& Pratiwi, A.W. 2009. Pengaruh kombinasi pupuk NPK dan TSP terhadap pertumbuhan, kadar air dan klorofil a Gracilaria verrucosa. Jurnal IImiah Perikanan dan Kelautan, 1(1):103-116.

Akmal, A., Syam, R. and Trijuno, D.D., 2012. Kandungan Klorofil a dan Karotenoid Rumput Laut Kappaphycus alvarezii yang Dibudidayakan pada Kedalaman Berbeda. Jurnal Octopus, 1(1): 54-58.

Budiyani, F.B., Suwartimah, K. \& Sunaryo. 2012. Pengaruh Penambahan Nitrogen dengan Konsentrasi yang berbeda terhadap Laju Pertumbuhan Rumput Laut Caulerpa racemosa var. Urivera. Journal of Marine Research, 1(1):10-18.

Campbell, N.A., Reece, J.B. \& Mithchell, L.G. 1999. Biology. University of Virginia, Virginia.

hrismadha, T., Panggabean, L.M. \& Mardiati, Y., 2006.. Pengaruh Konsentrasi Nitrogen dan Fosfor terhadap Pertumbuhan, Kandungan Protein, Karbohidrat dan Fikosianin pada Kultur Spirulina fusiformis. Jurnal Berita Biologi, 8(3):169-169.

Dwidjoseputro, D. 1980. Pengantar Fisiologi Tumbuhan. PT Gramedia, Jakarta.

Erlania, E., Nirmala, K. \& Soelistyowati, D.T. 2013. Penyerapan Karbon pada Budidaya Rumput Laut Kappaphycus alvarezii dan Gracilaria Gigas di Perairan Teluk Gerupuk, Lombok Tengah, Nusa Tenggara Barat. Jurnal Riset Akuakultur, 8(2):287-297.

Hartatik, W., Husnain, H. \& Widowati, L.R., 2015. Peranan Pupuk Organik Dalam Peningkatan Produktivitas Tanah dan Tanaman. Balai Penelitian Tanah. Jurnal Sumber Daya Lahan, 9(2):107-120.

Kushartono, E.W., Suryono, S. \& Setiyaningrum, E., 2009. Aplikasi Perbedaan Komposisi N, P dan K pada Budidaya Eucheuma cottonii di Perairan Teluk Awur, Jepara. IImu Kelautan, 14(3):164-169.

Kusmita, L. 2007. Formulasi Metode Ekstraksi Pigmen Klorofil. Program Studi Magister Biologi. UKSW. Salatiga

Ladyba, T. 2017. Pengaruh Pemberian Pupuk N dan P dengan Rasio N/P yang Berbeda terhadap Pertumbuhan dan Kandungan Protein Chlorella sp. Malang: Universitas Brawijaya

Ma'ruf, W.F., Ibrahim, R., Dewi, E.N., Susanto, E. \& Amalia, U. 2013. Profil Rumput Laut Caulerpa racemosa dan Gracilaria verrucosa sebagai Edible Food. Jurnal Saintek Perikanan, 9(1):6874.

Marschner, H. 1986. Mineral Nutrition of Higher Plants. Institute of Plant Nutrition Univ. Hohenheim. Fed.Rep. of Jerman.

Silviana, I.N. 2009. Pengaruh Kombinasi Pupuk Kompos dan NPK terhadap Pertumbuhan, Jumlah Klorofil a dan Kadar Air Gracilaria Verrucosa. Surabaya: Universitas Airlangga.

Yarti, N., Muhaemin, M. \& Hudaidah, S. 2014. Pengaruh Salinitas dan Nitrogen terhadap Kandungan Protein Total Nannochlorophis sp. Jurnal Rekayasa dan Teknologi Budidaya Perairan, 11(2): 76-277. 